\title{
Multiplication and Regeneration Potential in Strawberry genotypes using Different In Vitro Culture Methods and Growth Regulators
}

\author{
${ }^{1}$ Mohamed, F.H.; W.M.W. Elwan ${ }^{1}$, M.I.E. Abdoun ${ }^{1}$, F.H. and M.A.A. Hussein ${ }^{2}$ \\ ${ }^{1}$ Suez Canal University, Faculty of Agriculture, Department of Horticulture, Ismailia, Egypt \\ ${ }^{2}$ Suez Canal University, Faculty of Agriculture, Department of Agriculture Botany, Ismailia, Egypt
}

Received: 6/9/2018

\begin{abstract}
In vitro experiment was conducted at the Plant Tissue Culture Laboratory of the Department of Horticulture, Faculty of Agriculture, Suez Canal University, Ismailia, Egypt during the period 2015-2016. Effects of increasing number of subcultures up to $12^{\text {th }}$ subculture, BA concentrations up to $2.0 \mathrm{mg} / \mathrm{l}$ and their interaction on multiplication rate of four strawberry cultivars were studied. Also, organogenic potential of leaf disc explants from three strawberry cultivars were tested using two different media (direct and indirect regeneration medium). Presented results showed that the highest multiplication rate in cvs. Kamela and Amega were achieved after the $6^{\text {th }}$ subcultures using $1.0 \mathrm{mg} / 1 \mathrm{BA}$, however, the highest multiplication rate in cv. Camarosa was achieved after 7 subcultures using 1.0 $\mathrm{mg} / \mathrm{BA}$. The highest multiplication rate in cv. Fortuna was found after 6 subcultures on MS medium $+0.5 \mathrm{mg} / 1 \mathrm{BA}$, however, the lowest multiplication rate in all tested genotypes were after $12^{\text {th }}$ subculture on MS $+2.0 \mathrm{mg} / \mathrm{l} \mathrm{BA}$. High regeneration capacity was obtained in medium amended with TDZ (direct regeneration medium) compared with 2,4D+BA (indirect regeneration medium). Fortuna gave the highest regenerated shoots followed by cv. Kamela, then cv. Camarosa (v/v/v). Plantlets were successfully acclimated with $90 \%$ survival.
\end{abstract}

Keywords: Fragaria x ananassa, proliferation, regeneration, genotypes

\section{INTRODUCTION}

The commercial important Strawberry (Fragaria $\times$ ananassa Duch.) belongs to the family Rosaceae and is a member of the genus Fragaria L., which include 23 species (Rousseau-Gueutin et al. , 2009). The strawberry is valued for its low-calorie carbohydrate and high fiber contents and good sources of natural antioxidants (Wang et al., 1996) such as carotenoids, phenols, vitamins, flavonoids (Larson, 1988).

Strawberry is one of the main plants of horticultural interest, which are multiplied by micropropagation, compared with the conventional planting methods. Among the various methods developed to micro-propagate plants, enhanced axiallry branching culture has become the most important propagation method. This method is especially advantageous, because it is simple and the propagation rate is relatively high (Pierik, 1991). More importantly, it is generally considered to be an in vitro culture system with low risk of genetic instability (Pierik, 1991; Schoofs, 1992), because the organized mersitems are generally more resistant to genetic changes that might occur during cell division or differentiation under in vitro conditions (Vasil \& Vasil, 1980). The results of Diengngan et al. (2016) showed that the reproductive responses of in vitro propagated plants cv. Festival in the field were superior over the runner propagated plants.

Micropropagation of strawberry offers a number of advantages, such as increasing vigor and runner production in tissue-culture derived strawberry plants. More than one million plants can be micropropagated from a single meristem tip in a year. In addition, micropropagation allows rapid and flexible production of healthy, high-quality strawberry plants which are usually true-to-type (Hughes 2002). The economics of strawberry tissue culture industry is directly depending on the number of multiplication subcultures. As number of subcultures is increased (i.e. more than 8) then number of plantlets obviously increases which gives more profit. It is generally recommended not to exceed four to five subcultures to avoid loss of trueness-to type of the propagated material (Faedi et al., 2002). Libek and Kikas (2003) reported that the younger mericlones produce plants with higher runner production rates than older ones. During micropropagation, a high rate of proliferation is achieved in relatively shorter periods and leads to more frequent subculturing. Biswas et al. (2009) compare the strawberry produced from merstim tip, second subculture, twelfth subculture and control for their multiplication rate. Their results showed that multiplication rate did not differed significantly among meristem culture, after second and twelfth subcultures.

The results of Rodrigues et al. (1998) proved that somaclonal variants appeared from the fifth subculture $(1.3 \%)$ onwards and increased to $3.8 \%$ after 11 subcultures. Also, Biswass et al. (2009) found that one stables putative somaclone in plants produced from meristem tip and other one from twelfth subculture. However, da Fonseca et al. (2013) demonstrated that no differences between the two levels of subcultures (three and twelve subcultures) were observed. Also, Ayvaz-Sönmez and Kafkas (2016) examined the effect of subculture number up to 10 subcultures and the results showed that no dwarfism, chlorosis or white striping of leaves, multiapexing and stem fasciations, intensified vigour, hyperrunnering and abnormal flowering. In the same direction, EL-Sayed et al. (2017) studied the effect of increasing subculture number up to 6 subculture on multiplication rate of three cultivars and their results showed that the sixth subculture had the highest multiplication rate (3.6, 3.4 and 3.26 in cvs Sweet Charlie, Festival and Comarosa, respectively). 
Also from the advantages of in vitro culture, the direct and indirect shoot regeneration systems allow the production of variant plants, of which, some might show unique characteristics as new somaclones. Direct regeneration was observed in leaf disks which were given dark treatment and were cultured on MS+B5 vitamins $+2 \%$ glucose $+9.8 \mu \mathrm{M}$ TDZ (Husaini and Abdin, 2007). Thidiazuran (TDZ), a substituted phenyl urea, was recently incorporated into tissue culture media as a means of inducing regeneration as it acts as a substitute for both the auxin and cytokinin requirements of organogenesis in several species. TDZ is responsible for biosynthesis of cytokinin and preserves endogenous hormones in plant tissues and able to induce growth expansion and regeneration (Thomas and Katterman, 1986). Debnath (2005) reported an efficient in vitro system to regenerate shoots on excised sepals (calyx) of greenhouse grown strawberry using 2-4 $\mu \mathrm{M}$ TDZcontaining medium. The results of Mohamed et al. (2007) generally proved that the shoot regeneration occurred directly in medium amended with TDZ alone and the highest shoots number was in cv. "Festival" (8.6 shoots/explants). However, the shoot regeneration occurred indirectly (via callus phase) in a medium amended with TDZ +IBA and cv. "Chandler" gave the highest shoot number ( 6 shoots/explants). Biswas et al. (2010) found that $1.5 \mathrm{mg} / \mathrm{L} \mathrm{BA}+4.0 \mathrm{mg} / \mathrm{L} \mathrm{NAA}$ yielded the highest percentage of callus in all types of tested explants (leaf blade, nodal and runner segments). They added that the highest shoot regeneration rate was observed in leaf-derived callus on medium having 3 mg/l BA. Karim et al. (2011) were able to induce callus from 2-3 weeks old immature in vitro leaves on MS medium supplemented with $3.0 \mathrm{mg} / 1$ 2,4-D and $0.5 \mathrm{mg}$ BA. Indirect shoot regeneration was achieved on a medium amended with $0.5 \mathrm{mg} / 1 \mathrm{BA}+0.25 \mathrm{mg} / 1 \mathrm{NAA}$. Also, Karim et al. (2015) produced callus on MS medium supplemented with $2 \mathrm{mg} / \mathrm{l} \mathrm{NAA}+0.5 \mathrm{mg} / \mathrm{l} \mathrm{BA}$ and shoot regenerated indirectly by transferring the callus to the MS medium containing $1.5 \mathrm{mg} / \mathrm{BA}+0.75$ $\mathrm{mg} / 1 \mathrm{NAA}+0.5 \mathrm{mg} / \mathrm{l} \mathrm{Kin}$. Recently, Palei et al. (2017) studied callus induction and indirect regeneration from different strawberry explants. Callus was formed on MS medium BA with a callus FW $=170 \mathrm{mg}$. Shoots were indirectly regenerated from callus on $\mathrm{MS}+2.5 \mathrm{mg} / \mathrm{l} \mathrm{BA}$ $+0.5 \mathrm{mg} / 1 \mathrm{NAA}$ (average 5.1 shoot buds/culture).

The present study was designed to investigate the increasing subculture number up to $12^{\text {th }}$ subculture, BA concentrations during subculture and the interaction of on the in vitro multiplication rate of four strawberry cultivars. As well as, the response of strawberry genotypes to direct and indirect regeneration medium were examined.

\section{MATERIALS AND METHODS}

The experiment was conducted at the Plant Tissue Culture Laboratory of the Department of Horticulture, Faculty of Agriculture, Suez Canal University, Ismailia, Egypt during the period 20152016. Shoot tips of strawberry (Fragaria x ananassa) cvs. Camarosa, Fortuna, Kamela and Amiga were isolated from runners of greenhouse grown plants. The shoot tips were washed with running tap water several times, and surface sterilized by immersion in $70 \%(\mathrm{v} / \mathrm{v})$ ethanol for a few seconds, then soaked in a $20 \%$ Clorox (Commercial bleach $2.5 \%$ sodium hypochlorite) for 15 min with two drops of tween 20, which was used as a wetting agent. Thereafter, shoot tips were rinsed three times in sterile distilled water. Meristem tips $(5 \mathrm{~mm}$ long) were isolated under binuclear and cultured on solidified MS medium supplemented with $0.1 \mathrm{mg} / 1 \mathrm{BAP}$ (Murashige and Skoog 1962) and incubated until plantlets were obtained.

\section{First Experiment: In vitro multiplication}

To study the effect of BAP concentration on the multiplication rate of meristem tips up to 12 subcultures, derived shoots obtained from the previous stage were excised and subcultured on solidified multiplication MS medium containing $0.5 \mathrm{mg} / 1$ BAP up to fifth generation (subculture), then from sixth generation derived shoots were subcultured on MS medium containing $0.5,1.0,1.5$ and $2.0 \mathrm{mg} / 1 \mathrm{BAP}$ up to twelfth generation. The $\mathrm{pH}$ of the medium was adjusted at 5.6- 5.8. Meristem tips were cultured into glass culture jars $(50 \mathrm{ml})$ containing $10 \mathrm{ml}$ of the establishing MS hormone-free medium, derived shoots were subcultured onto $200 \mathrm{ml}$ jars containing $30 \mathrm{ml}$ of multiplication medium. Each treatment consisted of five replicates, each replicate consisted of one jar, which arranged in complete randomized design. Subcultures were done every four weeks into fresh medium of the same composition from sixth subculture till the twelfth subculture. All cultures of each treatment were incubated at $25 \pm 2^{\circ} \mathrm{C}$ under a $16 \mathrm{~h}$ day length with illumination of $100 \mu \mathrm{mol} / \mathrm{m}^{2} / \mathrm{S}^{-1}$ Osram cool white18 W fluorescent lamps. After each subculture starting from sixth subculture up to twelfth subculture, cultures were taken out of the culture jars in a laminar air- flow hood, examined for proliferated clump weight and number of shoots, then photographed under stereomicroscope. Growth observations were taken on the following parameters:

Shoots clump weight (g) - Shoots number/clump Average shoot weight (mg).

\section{Second experiment: direct and indirect regeneration from leaf explant}

Organogenic potential of leaf disc explants from four strawberry cultivars were tested in two medium types (M1 for direct and M2 for indirect regeneration). Three strawberry cultivars were utilized in this experiment, namely Camarosa, Fourtuna and Kamela. Leaf discs $(5 \times 5 \mathrm{~mm})$ from in vitro plantlets of the tested cultivars were excised and planted in two medium types to be tested for direct and indirect regeneration potential as follow:

Medium 1 (M1): MS salts and vitamins $+2.5 \mathrm{mg} / \mathrm{L}$ TDZ for 40 days, then transferred to $\mathrm{MS}+0.75 \mathrm{mg} / \mathrm{l} \mathrm{IBA}$ for elongation and rooting.

Medium 2 (M2): MS salts and vitamins $+1 \mathrm{mg} / 1$ 2,4-D $+0.5 \mathrm{mg} / \mathrm{l} \mathrm{BAP}$ under darkness for two weeks at $24 \pm 2^{\circ}$ $\mathrm{C}$, then under light (16/8 $\mathrm{hr}$ photoperiod) on the shelves of a growth room, then callus transferred to regeneration medium containing MS $+1 \mathrm{mg} / 1 \mathrm{BAP}+1 \mathrm{mg} / \mathrm{IAA}$ for 
two weeks. Regenerated shoots were transferred to hormone-free MS medium.

One leaf disc explant $(5 \times 5 \mathrm{~mm})$ was cultured with the adaxial surface touching the medium on $50 \mathrm{ml}$ glass jars amended with $10 \mathrm{ml}$ medium in a laminar airflow hood. For each cultivar, 5 replications, each containing one jar were utilized for each medium type in RCB design. Plantlets from each treatment obtained in the first stage were transferred into $200 \mathrm{ml}$ jars containing $30 \mathrm{ml}$ medium. At the end of culture for both treatments, cultures were taken out of the culture jars in a laminar air- flow hood, examined and photographed under stereomicroscope. Growth observations were taken on the following parameters:

1-Shoot clump weight ( $\mathrm{g}$ )

2-Number of shoots regenerated per explants

\section{Statistical analysis:}

The results were evaluated using descriptive statistics and analysis of variance (ANOVA). Using two-way ANOVA, the effect of BA concentrations, number of subcultures and their interactions were evaluated by Fisher's F-test, followed by Duncan's multiple range test at 0.05 level of probability for comparing the means separation. All tests were performed at a significance level $\alpha$ of 0.05 . Calculations were carried out using the software package Statistica ${ }^{\mathrm{TM}}$ for Windows version6.1 (Statsoft Inc., 2001, Tulsa, Oklahoma, USA).

\section{RESULTS AND DISCUSSION}

First Experiment: In vitro multiplication

A- Effect of subculture number, BA concentrations and their interaction on multiplication rate of $c v$. "Camarosa"

The presented results regarding to the main effect of number of subculture, BAP concentrations and their interaction on multiplication rate of cv. Camarosa showed that the shoot number, clump (shoot cluster) weight and average shoot weight were affected significantly by the BA concentrations, subculture number and their interaction (Table 1). Regarding to the main effect of number of subcultures, the highest shoot number per explant was significantly found after $7^{\text {th }}$ subcultures, and the significant lowest value was found after $12^{\text {th }}$ subcultures (Table 1). Regarding to clump weight, results proved that the highest significant value was found after $8^{\text {th }}$ subcultures, however the highest average shoot weight was found after 6 subcultures in comparison with the advanced subcultures. The significant lowest clump weight and average shoot weight were found after $9^{\text {th }}$ subcultures. Concerning to the main effect of BA concentrations, results showed that the highest of shoot number, clump weight and average shoot weight were attributed with $1 \mathrm{mg} / \mathrm{l} \mathrm{BA}$, however in most cases, the significant lowest shoot number, clump weight and average shoot weight were found with medium containing 0.5 and $2.5 \mathrm{mg} / 1 \mathrm{BA}$. Concerning to the interaction, results showed that the significant highest shoot number and non- significant highest clump weight were found after $7^{\text {th }}$ subcultures on MS medium containing $1 \mathrm{mg} / 1 \mathrm{BA}$, however, significant highest average shoot weight was found after $6^{\text {th }}$ subcultures on MS containing $0.5 \mathrm{mg} / 1$ BA. Results also showed that the lowest shoot number and clump weight were measured after $12^{\text {th }}$ subcultures on medium containing $2.5 \mathrm{mg} / 1 \mathrm{BA}$, however, lowest average shoot weight was found after $9^{\text {th }}$ subcultures on medium containing $1.5 \mathrm{mg} / 1 \mathrm{BA}$ (Table 1).

The presented results were in accordance with the results of Zobayer et al., 2011 and ElKichaoui (2014) who found that the best BA concentrations for multiplication in strawberry are 0.5 and $1 \mathrm{mg} / \mathrm{l}$. Also, El-Sayed et al. (2017) found that BA concentration at $0.5 \mathrm{mg} / \mathrm{l}$ was more effective for shoot multiplication in cv. "Camarosa" comparing with 0.1 and $0.25 \mathrm{mg} / \mathrm{l}$. The highest shoot number was detected at the $7^{\text {th }}$ subcultures and this result was comparable with the results of ElSayed et al. (2017) who found that the highest shoot number was found at $6^{\text {th }}$ subcultures. The indicated results showed that the lowest multiplication rate was found at $12^{\text {th }}$ subcultures and this result was supported with the findings of Libek and Kikas (2003) who reported that the younger mericlones produce plants with higher runner production rates than older ones. It is concluded that with the increase in number of subculture up to $12^{\text {th }}$ subcultures, the growth potential of cv. "Camarosa" decreased.

Table (1): Effect of number of subculture and BA Concentrations during the multiplication stage on the organogenic potential of strawberry cv. "Camarosa"

\begin{tabular}{|c|c|c|c|c|c|c|c|c|c|}
\hline Parameter & $\begin{array}{l}\text { Subcult. No. } \\
\text { BA Conc. } \\
\text { (mg/l) }\end{array}$ & 6 & 7 & 8 & 9 & 10 & 11 & 12 & Mean \\
\hline \multirow{5}{*}{$\begin{array}{l}\text { Shoot No./ } \\
\text { explants }\end{array}$} & 0.5 & $8.33 \mathrm{efg}$ & $11.33 \mathrm{cde}$ & $5.33 \mathrm{~g}$ & $4.33 \mathrm{~h}$ & $6.00 \mathrm{ghi}$ & $3.67 \mathrm{i}$ & $4.33 \mathrm{hi}$ & \multirow{5}{*}{$\begin{array}{l}6.19 \mathrm{~b} \\
11.28 \mathrm{a} \\
10.48 \mathrm{ab} \\
6.90 \mathrm{~b}\end{array}$} \\
\hline & 1.0 & 11.33 cde & $25.67 \mathrm{a}$ & $12.67 \mathrm{~cd}$ & $8.00 \mathrm{efg}$ & $8.00 \mathrm{efg}$ & $7.00 \mathrm{f}-\mathrm{i}$ & $6.33 \mathrm{ghi}$ & \\
\hline & 1.5 & $14.67 \mathrm{c}$ & $10.67 \mathrm{def}$ & $18.33 \mathrm{~b}$ & $8.33 \mathrm{efg}$ & $6.67 \mathrm{ghi}$ & $10.00 \mathrm{def}$ & $4.67 \mathrm{hi}$ & \\
\hline & 2.0 & $9.00 \mathrm{efg}$ & $7.67 \mathrm{e}-\mathrm{h}$ & $9.00 \mathrm{efg}$ & $6.67 \mathrm{ghi}$ & $7.00 \mathrm{f}-\mathrm{i}$ & $5.33 \mathrm{ghi}$ & $3.67 \mathrm{i}$ & \\
\hline & Mean & $10.83 \mathrm{~b}$ & $13.83 \mathrm{a}$ & $11.33 \mathrm{~b}$ & $6.83 \mathrm{~d}$ & $6.92 \mathrm{~d}$ & $6.5 \mathrm{~d}$ & $4.75 \mathrm{e}$ & \\
\hline \multirow{5}{*}{ Clumb weight (g) } & 0.5 & $0.606 \mathrm{~cd}$ & 0.422 def & $0.204 \mathrm{gh}$ & $0.178 \mathrm{~h}$ & $0.151 \mathrm{~h}$ & $0.12 \mathrm{~h}$ & $0.172 \mathrm{~h}$ & $0.265 \mathrm{~b}$ \\
\hline & 1.0 & $0.422 \mathrm{def}$ & $0.878 \mathrm{ab}$ & $0.760 \mathrm{bc}$ & $0.220 \mathrm{gh}$ & $0.218 \mathrm{gh}$ & $0.294 \mathrm{fgh}$ & $0.295 \mathrm{fgh}$ & 0.441 a \\
\hline & 1.5 & $0.775 \mathrm{bc}$ & $0.462 \mathrm{def}$ & $1.004 \mathrm{a}$ & $0.156 \mathrm{~h}$ & $0.223 \mathrm{gh}$ & $0.429 \mathrm{~d}-\mathrm{g}$ & $0.161 \mathrm{~h}$ & \multirow{3}{*}{$\begin{array}{l}0.458 \text { a } \\
0.241 \text { b }\end{array}$} \\
\hline & 2.0 & $0.247 \mathrm{fgh}$ & $0.305 \mathrm{e}-\mathrm{h}$ & $0.518 \mathrm{de}$ & $0.145 \mathrm{~h}$ & $0.156 \mathrm{~h}$ & $0.158 \mathrm{~h}$ & $0.158 \mathrm{~h}$ & \\
\hline & Mean & $0.513 \mathrm{~b}$ & $0.517 \mathrm{~b}$ & 0.622 a & $0.175 c$ & $0.187 \mathrm{c}$ & $0.225 \mathrm{c}$ & $0.197 \mathrm{c}$ & \\
\hline \multirow{5}{*}{$\begin{array}{c}\text { Average shoot } \\
\text { weight (mg) }\end{array}$} & 0.5 & $75.9 \mathrm{a}$ & $36.26 \mathrm{f}-1$ & $37.46 \mathrm{e}-\mathrm{k}$ & $41.93 \mathrm{~d}-\mathrm{i}$ & $25.47 \mathrm{j}-\mathrm{m}$ & $33.00 \mathrm{f}-\mathrm{m}$ & $41.19 \mathrm{~d}-\mathrm{i}$ & \multirow{5}{*}{$\begin{array}{l}41.60 \mathrm{a} \\
41.30 \mathrm{a} \\
40.00 \mathrm{a} \\
34.95 \mathrm{~b}\end{array}$} \\
\hline & 1.0 & $52.18 \mathrm{~b}-\mathrm{e}$ & $34.08 \mathrm{f}-1$ & $59.94 \mathrm{~b}$ & $26.41 \mathrm{i}-\mathrm{m}$ & $27.78 \mathrm{~h}-\mathrm{m}$ & $42.42 \mathrm{~d}-\mathrm{h}$ & $46.58 \mathrm{~b}-\mathrm{f}$ & \\
\hline & 1.5 & $53.60 \mathrm{bcd}$ & $43.37 \mathrm{~d}-\mathrm{g}$ & $53.78 \mathrm{bcd}$ & $18.83 \mathrm{~m}$ & $32.69 \mathrm{f}-\mathrm{m}$ & $42.97 \mathrm{~d}-\mathrm{h}$ & $34.78 \mathrm{f}-1$ & \\
\hline & 2.0 & $27.31 \mathrm{~h}-\mathrm{m}$ & $40.05 \mathrm{~d}-\mathrm{j}$ & $58.41 \mathrm{bc}$ & $21.82 \mathrm{~lm}$ & $22.31 \mathrm{klm}$ & $30.04 \mathrm{~g}-\mathrm{m}$ & $44.72 \mathrm{c}-\mathrm{g}$ & \\
\hline & Mean & 52.25 a & 38.44 b & 52.40 a & $27.25 \mathrm{c}$ & $27.06 \mathrm{c}$ & $37.11 \mathrm{~b}$ & $41.82 \mathrm{~b}$ & \\
\hline
\end{tabular}


$B$ - Effect of subculture number, BA concentrations and their interaction on multiplication rate of $c v$. "Fortuna"

The indicated results regarding to the effect of number of subculture, BAP concentrations and their interaction on multiplication rate of cv. "Fortuna" showed that the shoot number, clump weight and average shoot weight in most cases highly affected $(\mathrm{P} \leq 0.001)$ significantly by the $\mathrm{BA}$ concentrations, subculture number and their interaction, except only shoot number per explants which was not affected significantly by BA concentrations (Table 2). The highest shoot number per explant and clump weight were found after $6^{\text {th }}$ subcultures, however the lowest values of shoot number per explant and clump weight were found after $10^{\text {th }}$ and $12^{\text {th }}$ subcultures, respectively (Table 2). Regarding to average shoot weight, the presented results showed that the highest significant average shoot weight was observed after $12^{\text {th }}$ subcultures, however, the significant lowest average shoot weight was found after $10^{\text {th }}$ subcultures. Concerning to the main effect of BA concentration, the results proved that the concentrations of $\mathrm{BA}$ in the medium from 0.5 to $1.5 \mathrm{mg} / 1$ did not differ significantly regarding to the shoot number per explant and clump weight, although the highest shoot number was found at
$1.5 \mathrm{mg} / \mathrm{l} \mathrm{BA}$ and the highest clump weight was found at $0.5 \mathrm{mg} / \mathrm{l} \mathrm{BA}$. The highest average shoot weight values were detected at 0.5 and $1.0 \mathrm{mg} / 1 \mathrm{BA}$, however the lowest values of shoot number per explant, clump weight and average shoot weight were found at $2.0 \mathrm{mg} / 1$ BA. Concerning to the interaction of number of subculture $\mathrm{x}$ BA concentration, results showed that the highest shoot number and clump weight were found after 6 and 7 subcultures on MS medium containing 0.5 $\mathrm{mg} / \mathrm{l} \mathrm{BA}$, respectively, however, highest average shoot weight was found after 12 subcultures on MS containing $1.0 \mathrm{mg} / 1 \mathrm{BA}$. Results also showed that the lowest shoot number and clump weight were found after 12 subcultures on MS medium containing 0.5 and $1.5 \mathrm{mg} / 1$ BA, respectively, however, the lowest average shoot weight was found after $10^{\text {th }}$ subcultures on medium containing $2.0 \mathrm{mg} / \mathrm{l} \mathrm{BA}$ (Table 2). Our results were in the same direction with those obtained by El-Sayed et al. (2017) who found that the $6^{\text {th }}$ subcultures and the BA concentration up to $0.5 \mathrm{mg} / 1$ were the best for multiplication rate in three strawberry cultivars, namely "Camarosa", "Festival" and "Sweet Charlie". Also, the results of Zobayer et al., 2011 proved that the best BA concentration for high multiplication rate was $0.5 \mathrm{mg} / 1$ as reported by our results.

Table (2): Effect of number of subculture and BA Concentrations during the multiplication stage on the organogenic potential of strawberry cv. "Fortuna"

\begin{tabular}{|c|c|c|c|c|c|c|c|c|c|}
\hline Parameter & $\begin{array}{l}\text { Subcult. No. } \\
\text { BA Conc. } \\
(\mathrm{mg} / \mathrm{l})\end{array}$ & 6 & 7 & 8 & 9 & 10 & 11 & 12 & Mean \\
\hline \multirow{5}{*}{$\begin{array}{c}\text { Shoot No./ } \\
\text { explants }\end{array}$} & 0.5 & $12.00 \mathrm{a}$ & 10.33 a-e & $7.67 \mathrm{c}-\mathrm{g}$ & $5.00 \mathrm{ghi}$ & 5.33 ghi & $10.00 \mathrm{a}-\mathrm{f}$ & $3.33 \mathrm{i}$ & \multirow{5}{*}{$\begin{array}{l}7.67 \mathrm{ab} \\
7.57 \mathrm{ab} \\
8.33 \mathrm{a} \\
6.86 \mathrm{~b}\end{array}$} \\
\hline & 1.0 & $10.00 \mathrm{a}-\mathrm{f}$ & $8.33 \mathrm{~b}-\mathrm{g}$ & $8.00 \mathrm{~b}-\mathrm{g}$ & $7.33 \mathrm{~d}-\mathrm{h}$ & $8.33 \mathrm{~b}-\mathrm{g}$ & $7.00 \mathrm{e}-\mathrm{h}$ & $4.00 \mathrm{hi}$ & \\
\hline & 1.5 & $9.00 \mathrm{a}-\mathrm{f}$ & $8.33 \mathrm{~b}-\mathrm{g}$ & $11.33 \mathrm{ab}$ & $11.00 \mathrm{abc}$ & $7.33 \mathrm{~d}-\mathrm{h}$ & $7.00 \mathrm{e}-\mathrm{h}$ & $4.33 \mathrm{hi}$ & \\
\hline & 2.0 & $4.33 \mathrm{hi}$ & $6.67 \mathrm{f}-\mathrm{i}$ & $7.67 \mathrm{c}-\mathrm{g}$ & $10.67 \mathrm{a}-\mathrm{d}$ & $7.67 \mathrm{c}-\mathrm{g}$ & $7.00 \mathrm{efg}$ & $4.00 \mathrm{hi}$ & \\
\hline & Mean & $8.83 \mathrm{a}$ & 8.42 ab & $8.67 \mathrm{ab}$ & $8.50 \mathrm{ab}$ & $7.17 \mathrm{~b}$ & $7.75 \mathrm{ab}$ & $3.92 \mathrm{c}$ & \\
\hline \multirow{5}{*}{ Clumb weight (g) } & 0.5 & 0.448 a-d & $0.625 \mathrm{a}$ & $0.383 \mathrm{~b}-\mathrm{f}$ & $0.172 \mathrm{f}-\mathrm{i}$ & $0.130 \mathrm{hi}$ & $0.374 \mathrm{~b}-\mathrm{f}$ & $0.251 \mathrm{~d}-\mathrm{i}$ & \multirow{5}{*}{$\begin{array}{l}0.340 \text { a } \\
0.341 \text { a } \\
0.306 \text { ab } \\
0.250 \text { b }\end{array}$} \\
\hline & 1.0 & $0.574 \mathrm{ab}$ & $0.371 \mathrm{c}-\mathrm{f}$ & $0.419 \mathrm{~b}-\mathrm{e}$ & $0.254 \mathrm{~d}-\mathrm{i}$ & $0.244 \mathrm{~d}-\mathrm{i}$ & $0.217 \mathrm{f}-\mathrm{i}$ & $0.307 \mathrm{~d}-\mathrm{i}$ & \\
\hline & 1.5 & $0.501 \mathrm{abc}$ & $0.339 \mathrm{c}-\mathrm{h}$ & $0.382 \mathrm{~b}-\mathrm{f}$ & $0.253 \mathrm{~d}-\mathrm{i}$ & $0.192 \mathrm{f}-\mathrm{i}$ & $0.271 \mathrm{~d}-\mathrm{i}$ & $0.201 \mathrm{f}-\mathrm{i}$ & \\
\hline & 2.0 & 0.156 ghi & $0.311 \mathrm{c}-\mathrm{i}$ & $0.365 \mathrm{c}-\mathrm{g}$ & $0.221 \mathrm{e}-\mathrm{i}$ & $0.102 \mathrm{i}$ & $0.382 \mathrm{~b}-\mathrm{f}$ & $0.216 \mathrm{e}-\mathrm{i}$ & \\
\hline & Mean & 0.420 a & $0.410 \mathrm{a}$ & 0.390 ab & $0.225 \mathrm{~cd}$ & $0.167 d$ & 0.311 bc & $0.244 \mathrm{~cd}$ & \\
\hline \multirow{5}{*}{$\begin{array}{c}\text { Average shoot } \\
\text { weight (mg) }\end{array}$} & 0.5 & $38.63 \mathrm{~d}-\mathrm{j}$ & $59.08 \mathrm{~b}$ & $49.69 \mathrm{~b}-\mathrm{f}$ & $35.36 \mathrm{f}-\mathrm{k}$ & $24.52 \mathrm{i}-\mathrm{j}$ & $38.24 \mathrm{e}-\mathrm{j}$ & $75.77 \mathrm{a}$ & \multirow{5}{*}{$\begin{array}{l}45.90 \mathrm{a} \\
46.12 \mathrm{a} \\
39.05 \mathrm{~b} \\
38.82 \mathrm{~b}\end{array}$} \\
\hline & 1.0 & $55.96 \mathrm{bcd}$ & $44.74 \mathrm{~b}-\mathrm{h}$ & $51.91 \mathrm{~b}-\mathrm{f}$ & $34.55 \mathrm{f}-\mathrm{k}$ & $28.36 \mathrm{~h}-1$ & 30.41 g-k & $76.93 \mathrm{a}$ & \\
\hline & 1.5 & $55.50 \mathrm{~b}-\mathrm{e}$ & $40.77 \mathrm{c}-\mathrm{i}$ & 35.07 g-k & $23.05 \mathrm{jkl}$ & $26.83 \mathrm{i}-1$ & $39.40 \mathrm{~d}-\mathrm{j}$ & $45.72 \mathrm{~b}-\mathrm{h}$ & \\
\hline & 2.0 & $36.27 \mathrm{f}-\mathrm{k}$ & $45.67 \mathrm{~b}-\mathrm{h}$ & $46.06 \mathrm{~b}-\mathrm{g}$ & $20.87 \mathrm{kl}$ & 13.391 & $57.15 \mathrm{bc}$ & $52.31 \mathrm{~b}-\mathrm{e}$ & \\
\hline & Mean & $46.59 \mathrm{~b}$ & $47.57 \mathrm{~b}$ & $45.68 \mathrm{~b}$ & $29.46 \mathrm{c}$ & $23.38 \mathrm{c}$ & $41.30 \mathrm{~b}$ & $62.68 \mathrm{a}$ & \\
\hline
\end{tabular}

Values followed by the same letter within a column are not significantly different at the $0.05 \%$ level of probability according to Duncan's multiple range test

C- $\quad$ Effect of subculture number, BA concentration and their interaction on multiplication rate of $\mathrm{cv}$. "Kamela"

The indicated results regarding to the effect subculture number, BAP concentrations and their interaction on multiplication rate of cv. Kamela showed that the shoot number, clump weight and average shoot weight were highly affected $(\mathrm{P} \leq 0.001)$ significantly by the BA concentrations, subculture number and their interaction, except only average shoot weight which was not affected significantly by BA concentrations (Table 3 ). The significant highest shoot number per explant, clump weight and average shoot weight were recorded after $6^{\text {th }}$ subcultures, however the lowest value of shoot number per explant was found after $12^{\text {th }}$ subcultures and the non-significant lowest value of clump weight and average shoot weight were found after $10^{\text {th }}$ subcultures
(Table 3). Concerning the main effect of BA concentrations, the results proved that the concentrations of BA from 0.5 to $2.0 \mathrm{mg} / 1$ did not differ significantly regarding to the average shoot weight, although the highest average shoot weight was found at $0.5 \mathrm{mg} / 1 \mathrm{BA}$. The significant highest shoot number and clump weight values were detected at $1.5 \mathrm{mg} / 1 \mathrm{BA}$; however, the lowest values were found at $0.5 \mathrm{mg} / 1 \mathrm{BA}$. Concerning to the interaction, results showed that the non-significant highest shoot number, clump weight and average shoot weight were found after $6^{\text {th }}$ subcultures on MS medium containing $1.5,1.0$ and $2.0 \mathrm{mg} / 1 \mathrm{BA}$, respectively. The results also showed that the lowest shoot number was found after $12^{\text {th }}$ subcultures on medium containing $0.5 \mathrm{mg} / \mathrm{l} \mathrm{BA}$, however, lowest clump weight and average shoot weight were found after $10^{\text {th }}$ subcultures on medium containing $2.0 \mathrm{mg} / 1$ 
BA (Table 3). Our results were in the trend as the results obtained by El-Sayed et al. (2017) who found that the $6^{\text {th }}$ subcultures and the BA concentration up to $0.5 \mathrm{mg} / 1$ were the best for multiplication rate in three strawberry cultivars, namely "Camarosa", "Festival" and "Sweet Charlie". Also, the results of Zobayer et al. (2011) proved that the best BA concentrations for high multiplication rate were from $0.5-1.0 \mathrm{mg} / \mathrm{l}$.

\section{$D$ - Effect of subculture number, BA concentration and their interaction on multiplication rate of $c v$. "Amega"}

Effect of subculture number, BAP concentrations and their interaction on multiplication rate of cv. "Amega" were in most cases highly significant (Table 4). Results demonstrated that the significant highest shoot number per explants and clump weight over all BA concentrations was achieved after $6^{\text {th }}$ subcultures, while the least was found after $12^{\text {th }}$ subcultures (Table 4). Also, the results showed that the highest significant average shoot weight was calculated after $8^{\text {th }}$ subcultures, while the least was found after $9^{\text {th }}$ subcultures. Regarding to the main effect of BA concentrations, the presented results showed that the highest shoot number and clump weight were recorded on MS medium containing $1.0 \mathrm{mg} / 1 \mathrm{BA}$, while medium containing $0.5 \mathrm{mg} / \mathrm{l}$ gave the highest significant average shoot number. The least shoot number, shoot clump weight and average shoot weight were observed on MS medium containing $0.5, \quad 2.0$ and $1.5 \mathrm{mg} / \mathrm{l}$ BA respectively. The interaction of subculture number $\times \mathrm{BA}$ concentrations was significant at $\mathrm{P} \leq 0.05,0.001$ and 0.001 for shoot number, shoot clump weight and average shoot weight, respectively. The highest shoot number per explants and shoot clump weight were found when subculture number $6^{\text {th }}$ interacted with 1.5 and $1.0 \mathrm{mg} / \mathrm{BA}$, respectively. While, the least values of shoot number and clump weight were found at $2.0 \mathrm{mg} / 1$ BA in $12^{\text {th }}$ subcultures for both characters. Regarding to average shoot weight, results showed that the highest significant value was achieved in MS medium containing $0.5 \mathrm{mg} / 1 \mathrm{BA}$ after 8 subcultures, however the least value was detected at $1.5 \mathrm{BA}$ after $10^{\text {th }}$ subcultures. Our results were in accordance with the results of ElSayed et al. (2017) regarding the effect of subculture, who found that the $6^{\text {th }}$ subculture was the best for multiplication rate in three strawberry cultivars, namely "Camarosa", "Festival" and "Sweet Charlie". Also, the results of Zobayer et al., 2011 supported our results regarding to the effect of BA concentrations, who found that the $1.0 \mathrm{mg} / \mathrm{l} \mathrm{BA}$ was from the best concentrations for higher multiplication rate.

Table (3): Effect of number of subculture and BA Concentrations during the multiplication stage on the organogenic

\begin{tabular}{|c|c|c|c|c|c|c|c|c|c|}
\hline Parameter & $\begin{array}{l}\text { Subcult. No. } \\
\text { BA Conc. } \\
\text { (mg/l) }\end{array}$ & 6 & 7 & 8 & 9 & 10 & 11 & 12 & Mean \\
\hline \multirow{5}{*}{$\begin{array}{l}\text { Shoot No./ } \\
\text { explants }\end{array}$} & 0.5 & $13.33 \mathrm{~b}$ & $12.00 \mathrm{bc}$ & $10.00 \mathrm{~b}-\mathrm{f}$ & $5.33 \mathrm{f}-\mathrm{i}$ & 5.00 ghi & $4.33 \mathrm{hi}$ & $4.33 \mathrm{hi}$ & \multirow{5}{*}{$\begin{array}{l}7.76 \mathrm{bc} \\
8.90 \mathrm{~b} \\
10.91 \mathrm{a} \\
6.81 \mathrm{c}\end{array}$} \\
\hline & 1.0 & $19.33 \mathrm{a}$ & $7.33 c-i$ & $10.33 \mathrm{~b}-\mathrm{e}$ & 8.67 b-h & $8.00 \mathrm{~b}-\mathrm{i}$ & $4.33 \mathrm{hi}$ & $4.33 \mathrm{hi}$ & \\
\hline & 1.5 & $18.67 \mathrm{a}$ & $12.67 \mathrm{~b}$ & $10.67 \mathrm{~b}-\mathrm{e}$ & 8.67 b-h & $6.33 \mathrm{~d}-\mathrm{i}$ & $9.67 \mathrm{~b}-\mathrm{g}$ & $9.67 \mathrm{~b}-\mathrm{g}$ & \\
\hline & 2.0 & $11.00 \mathrm{bcd}$ & 5.00 ghi & $7.00 \mathrm{~d}-\mathrm{i}$ & $7.67 \mathrm{c}-\mathrm{h}$ & $6.00 \mathrm{e}-\mathrm{i}$ & $6.00 \mathrm{e}-\mathrm{i}$ & $5.00 \mathrm{ghi}$ & \\
\hline & Mean & $15.58 \mathrm{a}$ & $9.25 \mathrm{bc}$ & $9.50 \mathrm{~b}$ & $7.58 \mathrm{~cd}$ & $6.33 \mathrm{~d}$ & $6.08 \mathrm{~d}$ & $5.83 \mathrm{~d}$ & \\
\hline \multirow{5}{*}{$\begin{array}{c}\text { Clump weight } \\
\text { (g) }\end{array}$} & 0.5 & $0.173 \mathrm{fgh}$ & $0.488 \mathrm{bcd}$ & $0.456 \mathrm{bcd}$ & $0.150 \mathrm{gh}$ & $0.152 \mathrm{gh}$ & 0.156 gh & $0.395 \mathrm{~b}-\mathrm{f}$ & $0.281 \mathrm{c}$ \\
\hline & 1.0 & $0.516 \mathrm{~b}-\mathrm{f}$ & $0.687 \mathrm{~b}$ & $0.451 \mathrm{bcd}$ & $0.346 \mathrm{c}-\mathrm{h}$ & $0.221 \mathrm{e}-\mathrm{h}$ & $0.210 \mathrm{e}-\mathrm{h}$ & $0.173 \mathrm{fgh}$ & \multirow{4}{*}{$\begin{array}{l}0.372 \text { b } \\
0.469 \text { a } \\
0.317 \text { bc }\end{array}$} \\
\hline & 1.5 & $1.06 \mathrm{a}$ & $0.611 \mathrm{~b}$ & $0.419 \mathrm{~b}-\mathrm{e}$ & $0.353 \mathrm{c}-\mathrm{h}$ & $0.137 \mathrm{~h}$ & $0.401 \mathrm{~b}-\mathrm{e}$ & $0.305 \mathrm{c}-\mathrm{h}$ & \\
\hline & 2.0 & $0.892 \mathrm{a}$ & $0.281 \mathrm{~d}-\mathrm{h}$ & $0.369 \mathrm{c}-\mathrm{g}$ & $0.177 \mathrm{fgh}$ & $0.127 \mathrm{~h}$ & $0.220 \mathrm{e}-\mathrm{h}$ & $0.152 \mathrm{gh}$ & \\
\hline & Mean & $0.659 \mathrm{a}$ & $0.517 \mathrm{~b}$ & $0.424 \mathrm{~b}$ & $0.257 \mathrm{c}$ & $0.159 \mathrm{c}$ & $0.247 \mathrm{c}$ & $0.256 \mathrm{c}$ & \\
\hline \multirow{5}{*}{$\begin{array}{c}\text { Average shoot } \\
\text { weight (mg) }\end{array}$} & 0.5 & $49.51 \mathrm{cde}$ & $40.87 \mathrm{c}-\mathrm{g}$ & $45.91 \mathrm{cde}$ & $28.22 \mathrm{efg}$ & $30.36 \mathrm{efg}$ & $34.63 \mathrm{~d}-\mathrm{g}$ & $88.53 \mathrm{a}$ & \multirow{5}{*}{$\begin{array}{l}45.44 \mathrm{a} \\
44.13 \mathrm{a} \\
40.15 \mathrm{a} \\
43.80 \mathrm{a}\end{array}$} \\
\hline & 1.0 & $75.34 \mathrm{ab}$ & $35.31 \mathrm{~d}-\mathrm{g}$ & $44.04 \mathrm{c}-\mathrm{f}$ & $39.92 \mathrm{c}-\mathrm{g}$ & $28.01 \mathrm{efg}$ & $47.67 \mathrm{cde}$ & $38.63 \mathrm{c}-\mathrm{g}$ & \\
\hline & 1.5 & $57.99 \mathrm{c}$ & $47.86 \mathrm{cde}$ & $39.47 \mathrm{c}-\mathrm{g}$ & $41.26 \mathrm{c}-\mathrm{g}$ & $21.82 \mathrm{~g}$ & $41.55 \mathrm{c}-\mathrm{g}$ & $31.07 \mathrm{efg}$ & \\
\hline & 2.0 & $82.85 \mathrm{a}$ & $58.13 \mathrm{bc}$ & $53.02 \mathrm{~cd}$ & $23.31 \mathrm{fg}$ & $22.38 \mathrm{~g}$ & $36.68 \mathrm{~d}-\mathrm{g}$ & $30.25 \mathrm{efg}$ & \\
\hline & Mean & $66.42 \mathrm{a}$ & $45.54 \mathrm{~b}$ & $45.61 \mathrm{~b}$ & $33.18 \mathrm{c}$ & $25.64 \mathrm{c}$ & $40.13 \mathrm{~b}$ & $47.12 \mathrm{~b}$ & \\
\hline
\end{tabular}

Values followed by the same letter within a column are not significantly different at the $0.05 \%$ level of probability according to Duncan's multiple range test.

Table (4): Effect of number of subculture and BA Concentrations during the multiplication stage on the organogenic potential of strawberry cv. "Amiga"

\begin{tabular}{|c|c|c|c|c|c|c|c|c|c|}
\hline Parameter & $\begin{array}{l}\text { Subcult. No. } \\
\text { BA Conc. } \\
(\mathrm{mg} / \mathrm{l})\end{array}$ & 6 & 7 & 8 & 9 & 10 & 11 & 12 & Mean \\
\hline \multirow{5}{*}{$\begin{array}{c}\text { Shoot No./ } \\
\text { explants }\end{array}$} & 0.5 & $12.00 \mathrm{efg}$ & $14.33 \mathrm{de}$ & $8.00 \mathrm{f}-\mathrm{i}$ & $6.00 \mathrm{hij}$ & $5.67 \mathrm{hij}$ & $4.67 \mathrm{ij}$ & $4.67 \mathrm{ij}$ & \multirow{5}{*}{$\begin{array}{l}7.90 \mathrm{~b} \\
11.48 \mathrm{a} \\
11.05 \mathrm{a} \\
8.20 \mathrm{~b}\end{array}$} \\
\hline & 1.0 & $22.33 \mathrm{ab}$ & $18.67 \mathrm{bc}$ & $13.33 \mathrm{de}$ & $10.00 \mathrm{e}-\mathrm{h}$ & $6.33 \mathrm{hij}$ & $5.67 \mathrm{hij}$ & $4.00 \mathrm{ij}$ & \\
\hline & 1.5 & $24.67 \mathrm{a}$ & $12.00 \mathrm{ef}$ & $8.33 \mathrm{f}-\mathrm{i}$ & $11.00 \mathrm{efg}$ & $8.00 \mathrm{f}-\mathrm{i}$ & $8.00 \mathrm{f}-\mathrm{i}$ & $5.33 \mathrm{ij}$ & \\
\hline & 2.0 & $17.00 \mathrm{~cd}$ & $12.00 \mathrm{ef}$ & $6.67 \mathrm{~g}-\mathrm{j}$ & $8.00 \mathrm{f}-\mathrm{i}$ & $7.33 \mathrm{~g}-\mathrm{j}$ & $6.33 \mathrm{hij}$ & $3.00 \mathrm{j}$ & \\
\hline & Mean & $19.00 \mathrm{a}$ & $15.17 \mathrm{~b}$ & $9.08 \mathrm{c}$ & $8.75 \mathrm{c}$ & $6.83 \mathrm{~d}$ & $6.17 \mathrm{~d}$ & $4.25 \mathrm{e}$ & \\
\hline \multirow{5}{*}{$\begin{array}{c}\text { Clump weight } \\
\text { (g) }\end{array}$} & 0.5 & 0.612 def & 0.612 def & 0.667 cde & $0.281 \mathrm{~g}$ & $0.231 \mathrm{~g}$ & $0.131 \mathrm{~g}$ & $0.271 \mathrm{~g}$ & \multirow{5}{*}{$\begin{array}{l}0.401 \text { ab } \\
0.503 \text { a } \\
0.414 \text { ab } \\
0.354 \text { b }\end{array}$} \\
\hline & 1.0 & $1.125 \mathrm{a}$ & 0.718 cde & $0.781 \mathrm{bcd}$ & $0.331 \mathrm{fg}$ & $0.189 \mathrm{~g}$ & $0.207 \mathrm{~g}$ & $0.172 \mathrm{~g}$ & \\
\hline & 1.5 & $0.936 \mathrm{abc}$ & $0.634 \mathrm{c}-\mathrm{f}$ & $0.317 \mathrm{fg}$ & $0.338 \mathrm{fg}$ & $0.191 \mathrm{~g}$ & $0.342 \mathrm{fg}$ & $0.144 \mathrm{~g}$ & \\
\hline & 2.0 & $1.03 \mathrm{ab}$ & $0.423 \mathrm{efg}$ & $0.268 \mathrm{~g}$ & $0.149 \mathrm{~g}$ & $0.230 \mathrm{~g}$ & $0.275 \mathrm{~g}$ & $0.099 \mathrm{~g}$ & \\
\hline & Mean & 0.926 a & 0.597 b & $0.508 \mathrm{~b}$ & $0.274 \mathrm{c}$ & $0.210 \mathrm{c}$ & 0.239 c & 0.172 c & \\
\hline \multirow{5}{*}{$\begin{array}{c}\text { Average shoot } \\
\text { weight (mg) }\end{array}$} & 0.5 & $50.51 \mathrm{~b}-\mathrm{e}$ & $42.32 \mathrm{~b}-\mathrm{g}$ & $87.68 \mathrm{a}$ & $46.68 \mathrm{~b}-\mathrm{f}$ & $40.47 \mathrm{~b}-\mathrm{g}$ & $25.28 \mathrm{fg}$ & $58.93 \mathrm{bc}$ & \multirow{5}{*}{$\begin{array}{l}50.27 \text { a } \\
42.31 \text { b } \\
35.09 \text { b } \\
35.73 \text { b }\end{array}$} \\
\hline & 1.0 & $60.63 \mathrm{~b}$ & $32.09 \mathrm{~d}-\mathrm{g}$ & $60.88 \mathrm{~b}$ & $33.07 \mathrm{~d}-\mathrm{g}$ & $29.41 \mathrm{~d}-\mathrm{g}$ & $35.89 \mathrm{c}-\mathrm{g}$ & $44.19 \mathrm{c}-\mathrm{f}$ & \\
\hline & 1.5 & 30.99 d-g & $53.41 \mathrm{bcd}$ & 28.36 b-g & $29.35 \mathrm{~d}-\mathrm{g}$ & $23.21 \mathrm{fg}$ & $43.26 b-f$ & $27.06 \mathrm{efg}$ & \\
\hline & 2.0 & $38.63 \mathrm{~b}-\mathrm{g}$ & $35.40 \mathrm{c}-\mathrm{g}$ & $40.04 \mathrm{~b}-\mathrm{g}$ & $18.76 \mathrm{~g}$ & $38.85 \mathrm{~b}-\mathrm{g}$ & $46.04 \mathrm{~b}-\mathrm{f}$ & $33.36 \mathrm{~d}-\mathrm{g}$ & \\
\hline & Mean & $45.79 \mathrm{~b}$ & 40.80 bc & $56.74 \mathrm{a}$ & 31.97 c & 32.99 c & $37.62 \mathrm{c}$ & 40.89 bc & \\
\hline
\end{tabular}

Values followed by the same letter within a column are not significantly different at the $0.05 \%$ level of probability according to Duncan's multiple range test. 
Second Experiment: direct and indirect regeneration from leaf explant

Results (Table 5) demonstrated that both medium types (M1 for direct regeneration and M2 for indirect shoot regeneration) had resulted in the formation of shoot proliferated clump in a medium supplemented with TDZ which produced direct shoot regeneration without callus from the surface of leaf segment explants. While, MS medium amended with 2,4-D and BAP, then BAP and IAA produced shoots from callus tissue, both after $\geq 40$ days for culture initiation. Shoot derived from direct regeneration were significantly higher in number $(\mathrm{x}=18.8)$ compared to these derived from callus phase $(x=12.2)$. Significant differences among the examined cultivars were found for their regeneration capacity (Table 5). In this respect, the average number of shoot was the highest $(x=19.25)$ in explants from cv. "Fortuna", while the least shoot number (12.86) was detected on the surface of leaf explants of cv. "Camarosa". Number of shoots was not significantly different between cv. "Camarosa" and cv. "Kamela" (12.86 and 14.14, respectively). The interaction of media $\mathrm{x} \mathrm{cv}$ was not significant since all 4 cultivars had similar response to medium type. The highest shoot number was found in cv. "Fortuna" (24.75) on M1 medium, followed by "Kamela" (18 shoots) on the same medium. The number of shoot/explants was the least on M2 medium for both cvs "Camarosa" and "Kamela" (11.75 and 11.25, respectively).

Genotypic differences in response to in vitro culture at a given concentration of growth regulators in current investigation were expected, as this had been observed previously by other workers (Simpson and Bell, 1989; Passey et al., 2003; Singh and Pandey, 2004; Landi and Mezzetti, 2006; Mohamed et al., 2007). This different behavior can be related to the fact that different genotypes have different mechanisms of controlling the endogenous plant growth regulators metabolism and/or contents. Regeneration efficiency or organogenetic ability was suggested to be under control of specific genes that are inducible (Hodges et al.,
1986). High regeneration capacity obtained in this study with TDZ as the cytokinin source in the culture medium may be explained on the basis of its extremely high cytokinin activity and stability in plant tissue (Lu, 1993; Murthy et al., 1998). The efficiency of TDZ for in vitro regeneration of strawberry has been reported (Hassan, 1996; Landi and Mezzetti, 2006; Passey et al., 2003; Mohamed et al., 2007). TDZ is able to induce diverse morphogenic responses ranging from tissue proliferation to adventitious shoot and somatic embryo formation (Omer et al., 2012).

Broertjes and keen (1980) had pointed out that the apex of an adventitious shoot was formed by one or a few vegetative daughter cells of one original cell. However, many researchers believed that shoots could be multicellular and multihistogenic in origin (Marcotrigiano, 1986) and this was confirmed later by Zhu et al. (2007).

The process of plant regeneration from callus in strawberry is often associated with more somaclonal variation than other modes of regeneration. The Occurrence of polyploidy and aneuploid changes in long-term callus cultures of strawberry has been reported (Nehra et al., 1991, 1992). Additionally, some of the cytological abnormalities observed in long-term callus cultures are passed onto regenerants from such cultures (Nehra et al., 1992; Popescu et al., 1997).

The presence of disorganized growth phase in tissue culture is considered as a major feature that cause somaclonal variation (Rani and Raina, 2000). Tissue culture systems subject to instability and disorganized growth (non-meristem explant culture) demonstrated that cellular organization is a critical feature and that somaclonal variation is related to disorganized growth. Generally, the more the organizational structure of the plant is broken down, the greater the chance of mutations occurring. As a consequence, highly differentiated tissues (roots, leaves, stems) generally produce more variants than explants from axillary buds and shoots tips that have pre-existing meristems (Bairu et al., 2011).

Table (5): Main effect of medium type, cultivars and their interaction on shoot cluster fresh weight and number of shoots/cluster

\begin{tabular}{|c|c|c|c|c|c|c|}
\hline & \multicolumn{2}{|c|}{ Clump weight (g) } & \multirow{2}{*}{ Mean } & \multicolumn{2}{|c|}{ Shoots No. } & \multirow{2}{*}{ Mean } \\
\hline & M1 & M2 & & M1 & M2 & \\
\hline Camarosa & $0.72 \mathrm{~b}$ & $0.37 \mathrm{c}$ & 0.52 ab & $14.33 \mathrm{bc}$ & $11.75 \mathrm{c}$ & $12.86 \mathrm{~b}$ \\
\hline Fourtona & $0.37 \mathrm{c}$ & $0.43 \mathrm{c}$ & 0.40 bc & $24.75 \mathrm{a}$ & $13.75 \mathrm{bc}$ & $19.25 \mathrm{a}$ \\
\hline Kamela & $1.19 \mathrm{a}$ & $0.25 \mathrm{c}$ & 0.65 a & $18.00 \mathrm{~b}$ & $11.25 \mathrm{c}$ & $14.14 \mathrm{~b}$ \\
\hline Mean & 0.60 a & $0.34 \mathrm{~b}$ & & $18.79 \mathrm{a}$ & $12.19 \mathrm{~b}$ & \\
\hline \multicolumn{7}{|c|}{ Significance } \\
\hline cvs & \multicolumn{2}{|c|}{$* * *$} & \multicolumn{4}{|c|}{$*$} \\
\hline Media (M) & \multicolumn{2}{|c|}{$* * *$} & \multicolumn{4}{|c|}{$* * *$} \\
\hline Cvs $x$ M & \multicolumn{2}{|c|}{$* * *$} & \multicolumn{4}{|c|}{ Ns } \\
\hline
\end{tabular}

In vitro tissue culture techniques have been known as an important tool in the induction of variation leading to the development of new plant genotypes (Larkin and Scowcroft, 1981). This source of variation is considered as a useful tool for geneticists and plant breeders. Somaclonal variation is cheaper than other methods of genetic manipulation and provides a successful tool in crops with limited genetic systems and/or narrow genetic bases where it can provide a rapid source of variability for crop improvement. Detected variation in plants regenerated from callus cultures or 
adventitious shoot formation of cvs. Camarosa, Fourtona and Kamela can be considered somaclones that might develop new cultivars adaptive to stress condition or disease tolerant.

\section{CONCLUSION}

Increasing subculture number up to $6^{\text {th }}$ or $7^{\text {th }}$ subculture is suitable for multiplication using low BA concentration $(0.5 \mathrm{mg} / \mathrm{l})$ to produce plantlets similar to mother plants. It could be possible to regenerate strawberry plantlets from leaf disc explants directly or indirectly (through callus phase).

\section{REFERENCES}

Ayvaz-Sönmez D., S. Kafkas (2016). Genetic stability of 'Festival' and 'Rubigem' cultivars in different subcultures by SSR markers. Acta Hortic. 1156, 877-882.

Bairu, M.W., A.O. Aremu, J. Van Staden (2011). Somaclonal variation in plants: causes and detection methods. Plant Growth Regul., 63(2); 147-173.

Biswas M. K., M. Dutt, U. K. Roy, R. Islam and M. Hossain (2009). Development and evaluation of in vitro somaclonal variation in strawberry for improved horticultural traits. Sci. Hortic., 122(3): 409-416.

Biswas, M.K., U.K. Roy, R. Islam, M. Hossain (2010). Callus culture from leaf blade, nodal, and runner segments of three strawberry (Fragaria $s p$.) clones. Turk.J. Biol, 34, 75-80.

Broertjes, C., A. Keen (1980). Adventitious shoots: Do they develop from one cell? Euphytica 29, (1): 73-87.

da Fonseca, A.P.; E. C. da SilvaI, M. B. PereiraI, R. P. de Oliveira and A. L. C. Dornelles (2013). Phenotypic stability of strawberry genotypes subjected to variable number of in vitro subcultures. Ciência Rural, Santa Maria: 43(8), 1345-1350.

Debnath, S.C. (2005). Strawberry sepal: another explant for thidiazuron-induced adventitious shoot regeneration in vitro Cell. Dev. Biol. Plant. 41(5): 67-76.

Diengngan, S.; M. Mahadevamma and B. N. Srinivasa Murthy (2016). Efficacy of in vitro Propagation and Crown Sizes on the Performance of Strawberry (Fragaria $\times$ ananassa Duch) cv. Festival under field condition. J. Agr. Sci. Tech. (18): 255-264.

ElKichaoui, A. Y. (2014). In vitro, Propagation of strawberry (Fragaria $\times$ annanasa Duch.) through Organogenesis via runner tips. Ann. Plant Sci. 3(3):619-627.

EL-Sayed, S. F., A.E. Mohamed, Sahar S. Taha, Manal S. H. Gomah (2017). Effect of benzyl amino purine concentration and number of subcultures on behavior of some strawberry cultivars in vitro. Egypt. J. Plant Breed. 21(1):1 - 12.
Faedi, W., F. Mourgues and C. Rosati (2002). Strawberry breeding and varieties: situation and perspectives. Acta Hortic., 567: 51-59.

Hassan, M.A. (1996). In vitro shoot regeneration from strawberry leaf tissues. Zagazig J. Agric. Res., 23: 101-113.

Hodges, T.K., K.K. Kamo, C.W. Imbrie, M.R. Becwar (1986). Genotype specificity of somatic embryogenesis and regeneration in maize. Biotechnol., 4: 219-223.

Hughes B.R. (2002). Proc. 5th N. Amer. Strawberry Conf.: $\quad$ Strawberry Res.To 2001 Micropropagated strawberries in the Ontario plant propagation program, eds Hokanson S.C., Jamieson A.R. (ASHS Press, Alexandria, VA), pp 93-97.

Husaini A.M., M.Z. Abdin (2007). Interactive effect of light, temperature and TDZ on the regeneration potential of leaf discs of Fragaria $\times$ ananassa Duch. In Vitro Cell Dev. Biol. Plant 43:576584.

Karim, M. R., A. M. Azis, U. Krishna, M. Aminul and M. Monzur (2011). In vitro response of strawberry (Fragaria $\mathrm{x}$ ananassa Dutch.) for callus induction and shoot regeneration. Inter. J. Agron. Agric. Res. 1(1), 29-36.

Karim, R., F. Ahmed, U. Krishna Roy, T. Ara, R. Islam and M. Hossain (2015). Varietal improvement of strawberry (Fragaria x ananassa Dutch) through somaclonal variation using in vitro techniques. J. Agric. Sci. Tech. 17:977-986.

Landi, L., B. Mezzetti (2006). TDZ, auxin and genotype effects on leaf organogenesis in Fragaria. Plant Cell Rep. 25:281-288.

Larkin P., W.R. Scowcroft (1981). Somaclonal variation, a novel source of variability from cell cultures for plant improvement. Theor. Appl. Genet. 60: 197-214.

Larson R. A. (1988). The antioxidants of higher plants. Phytochem., 27 (4): 969- 978.

Libek, A. and A. Kikas (2003). Influence of different planting material on production of strawberry runner plants. Agron. Res. 1, 69-74.

Lu, C.Y. (1993). The use of TDZ in tissue culture. In Vitro Cell. Dev. Biol.- Plant 29: 92-96.

Marcotrigiano, M. (1986). Origin of adventitious shoots regenerated from cultured tobacco leaf tissue. Am. J. Bot. 73: 1541-1547.

Mohamed F. H., M. S. Beltagi, M. A. Ismail and G. F. Omar (2007). High frequency, direct shoot regeneration from greenhouse-derived leaf disks of six strawberry cultivars. Pakistan J. Bio. Sci., 10(1): 96-101.

Murashige T. and F. Skoog (1962). A revised medium for rapid growth and bioassays with tobacco cultures. Physiol. Plant 15: 473-497.

Murthy, B.N.S., S.J. Murch, P.K. Saxena (1998). Thidiazuron: a potent regulator of in vitro plant morphogenesis. In Vitro Cell. Dev. Biol. Plant 34:267-275.

Nehra N.S., K.K. Kartha, C. Stushnoff, K.L. Giles (1992). The influence of plant growth regulator concentrations and callus age on somaclonal 
variation in callus culture regenerants of strawberry. Plant Cell Tiss. Org., 29:257-268.

Nehra N.S., K.K. Kartha, C. Stushnoff (1991). Nuclear DNA content and isozyme variation in relation to morphogenic potential of strawberry (Fragaria $\times$ ananassa Duch.) callus cultures. Can. J. Bot. 69: 239-244.

Omer, G.F., F.H. Mohamed, K.T. Haensch, M. Morsy, S. Hassan (2012). Evaluation of the efficiency and TDZ and picloram for the induction of somatic embryos in strawberry. Agric. Res. J. Suez Canal Univ. 12:40-50.

Palei, S., G. R. Rout, A. K. Das and D. K. Dash (2017). Callus induction and indirect regeneration of strawberry ((Fragaria $x$ ananassa Duch. cv. Chandler). Int. Curr. Microbiol. App. Sci. 6(11):1311-1318.

Passey, A.J., K.J. Barrett, D.J. James (2003). Adventitious shoot regeneration from seven commercial strawberry cultivars (Fragaria $\times$ ananassa Duch.) using a range of explant types. Plant Cell Rep. 21:397-401.

Pierik, R.L.M. (1991). In: Horticulture. New technologies and applications, J. Prakash, R.L.M. Pierik (eds.). Kluwer Acad. Publ., Dordrecht, The Netherlands 141-153.

Popescu, A.N., V.S. Isac and M.S.R. Coman (1997). Somaclonal variation in plants regenerated by organogenesis from callus cultures of strawberry (Fragaria $\times$ ananassa). Acta Hortic., 439:89-96.

Rani, V. and S.N. Raina (2000). Genetic fidelity of organized meristem-derived micropropagated plants: a critical reappraisal. In Vitro Cell Dev. Biol. Plant. 36:319-30.

Rodrigues, P.H.V., A. Tulmann Neto, P. Cassieri Neto and B.M.J. Mendes (1998). Influence of the number of subcultures on somoclonal variation in micropropagated Nanico (Musa spp., AAA group). Acta Hortic. 490:469-473.

Schoofs, J. (1992). Rapid clonal propagation storage and exchange of Musa species In: Baker, F.W.G. (ed.), Rapid Propagation of Fast Growing Woody Species, CAB International, Oxon, U.K. 29-40.

Simpson, D.W. and J.A. Bell (1989). The response of different genotypes of Fragaria annanasa and their seedling progenies to in vitro micropropagation and the effect of varying the concentration of 6-benzylaminopurine in the proliferation medium. Plant Cell Tiss. Org. 17: 225-234.

Singh, A.K. and S.N. Pandey (2004). Genotypic variation among strawberry cultivars for shoot organogenesis. Acta Hort. 662: 277-280.

Thomas, J.C. and F.R. Katterman (1986). Cytokinin activity induced by thidiazuron. Plant Physiol. 81: 681-683.

Vasil, V. and K. Vasil (1980). Isolation and culture of cereal protoplasts. Theor. Appl Genet. 56(3): 97-99

Wang H., G. Cao and R. L. Prior (1996). Total antioxidant capacity of fruits. J. Agr. Food. Chem., 44:701-705.

Zhu, X.Y., M. Zhao, S. Ma, Y.M. Ge, M.F. Zhang and L.P. Chen (2007). Induction and origin of adventitious shoots from chimeras of Brassica juncea and Brassica oleracea. Plant Cell Rep. 26(10): 1727-1732.

Zobayer, N.; H. S. Prodhan, S. U. Sikdar, F. Azim and M. Ashrafuzzaman (2011). Study of shoot multiplication of strawberry (Fragaria ananassa). Int. J. Agril. Res. Innov. \& Tech. 1 (1\&2): 69-72.

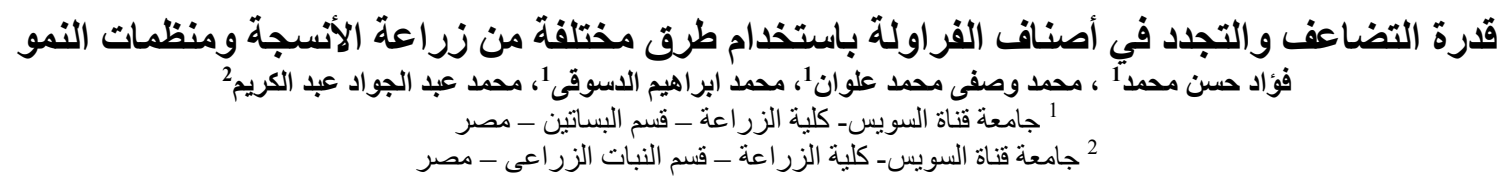

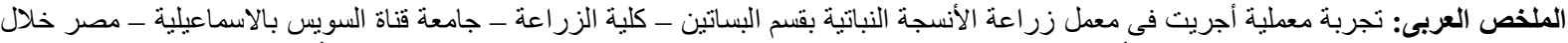

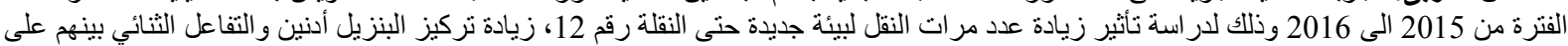

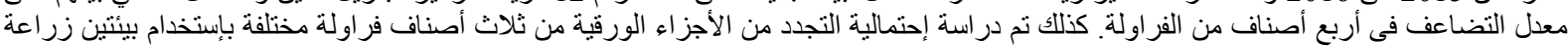

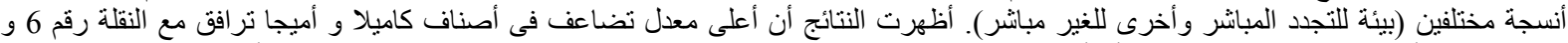

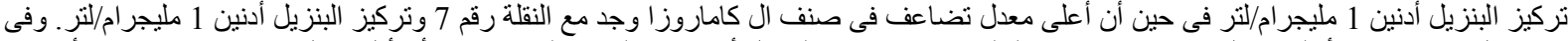

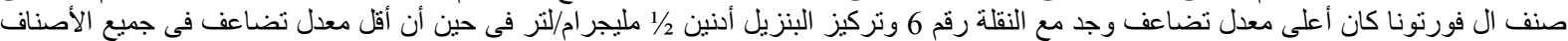

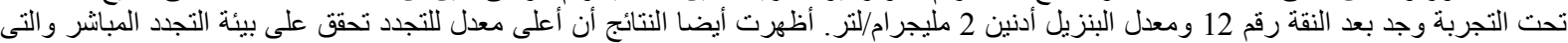

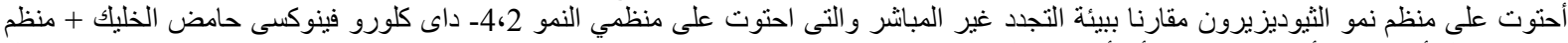

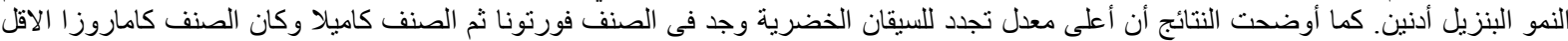

